\title{
TRADD wt Allele
}

National Cancer Institute

\section{Source}

National Cancer Institute. TRADD wt Allele. NCI Thesaurus. Code C52443.

Human TRADD wild-type allele is located in the vicinity of $16 q 22$ and is approximately 6 $\mathrm{kb}$ in length. This allele, which encodes tumor necrosis factor receptor type 1-associated DEATH domain protein, plays a role in the regulation of tumor necrosis factor receptor programmed cell death. 